\title{
THE ACTIVITIES OF THE ESTONIAN NATURALISTS' SOCIETY IN 2012
}

\author{
Tõnu VIIK, Ivar OJaste \\ Estonian Naturalists' Society, Estonia
}

\begin{abstract}
The activities of the Estonian Naturalists' Society in 2012 are described.
\end{abstract}

Keywords: naturalists, society

\section{INTRODUCTION}

The Estonian Naturalists' Society (ENS) will be 160 in October 2013. During this long time our society has seen both bad and happy days - many wars have been fought on Estonian soil in this period. Despite that we survived and are continuing our work in the field of natural sciences, and according to our statute we have been disseminating the knowledge of nature among the Estonian population. Since 1998 we are associated with the Estonian Academy of Sciences. This means that the state finances us through the academy and the Ministry of Education and Research. We earn a substantial part of our expenditures by carrying out different projects at diverse organisations among which the most important is the Centre of Environmental Investments.

Our activities are carried out in 22 subunits by 718 active members. These subunits are relatively autonomous and they present their annual reviews in March of the following year. Some of the subunits work as sections: amateur meteorologists, anthropology, botany, entomology, forestry, geology, theoretical biology. The other subunits are: the Commission of Lakes, the Estonian Society of Malacology, the Estonian Mycological Society, the Estonian Society of Theriology and the Jakob von Uexküll Centre. Commissions with special tasks focus on the history of natural sciences, the library, natural education, observation networks, terms of ecology and plant names, botanical rarities. Last 
but not least, the Society has assemblies of ecology, of honorary members and the round table of nature conservation.

\section{THE ACTIVITIES OF THE SOCIETY}

In 2012 eight General Assemblies with scientific presentations and one special meeting were held:

January 26 - Meelis Pärtel: "Secret value of plant richness”.

February 28 - “The Baer day”, presentations by Michael von Lingen and Erki

Tammiksaar.

March 8 - Conference "100 anniversary of Eerik Kumari”.

March 29 - Rein Rõõm: „Physics of climate change“.

April 26 - Eero Vasar: "Research of LSAMP-gene". The annual review of the activities in 2011 was presented.

September 27 - Ülo Mander: "Climate change and Estonia“.

October 25 - Ivar Ojaste: "Habitat requirement of Capercaillie”.

November 22 - 120 anniversary of Teodor Lippmaa. Presentations by Hans

Trass: "Life and scientific activity of Teodor Lippmaa", Martin Zobel:

"Research of plant community ecology after Teodor Lippmaa".

December 20 - Ülo Niinemets: "Stress hormones of plants and its impact to climate”.

A seminar about "Wolf, sheep and human" was organized on January 12 . The main topics were about ecology of wolf and its conflict with farmers on Saaremaa island. Scientists from Estonian Environment Information Centre, University of Helsinki, Tallinn University, University of Tartu and representatives of Estonian Environmental Board and local farmers participated in this seminar. The moderator was Marek Sammul (Estonian University of Life Sciences).

The $35^{\text {th }}$ Naturalists' Day was held at Tihemetsa, Pärnu county June 30 till July 1.

We are very proud that after Mart Niklus had translated the Charles Darwin's book "The Origin of Species by Means of Natural Selection, or the Preservation of Favoured Races in the Struggle for Life" 40 years ago into Estonian language we were able to present this book to the Estonian public. This important event took place on September 20. This book was edited by Mart Viikmaa, Ivar Puura and Oive Tinn. This book is the second in the series "Classics in Natural Science". The subunits of ENS organized their traditional and other events. 
Meetings of section of geology were held:

1. February 7, presentation by Sébastien Joannin "Lyon (France) - Beijing (China) by bicycle: The sport challenge and scientific expedition of a palaeontologist"

2. March 9, presentations by Helje Pärnaste "Focus on trilobites" and Allan Selin "Nowadays insects"

3. April 12, presentation by Alar Rosentau "Littorina Sea and the Stone Age on Bay Narva-Luuga”

The $8^{\text {th }}$ Autumn School of Geology "Catastrophes during the Earth history" took place at Nelijärve, Harju county, October 5-7. This seminar was organized together with Doctoral School of Earth Sciences and Ecology. During three days 18 scientific reports were presented.

Jakob von Uexküll Centre organized a Summer School of Ecosemiotics at Karula, August 3-4. During this days 9 reports on biosemiotics, ecosemiotics and environmental humanities were presented.

Two exhibitions using the material of archive of Jakob von Uexküll Centre were organized: first to the participants of the conference "Gatherings in Biosemiotics 12", Tartu, July 16-21. The second exhibition took place during the meeting of Jakob von Uexküll Centre at Struve 2, Tartu, December 6, when the book about Jakob von Uexküll was presented.

Jakob von Uexküll Centre was co-organizer together with International Society for Biosemiotic Studies and Department of semiotics of the University of Tartu of the conference "Gatherings in Biosemiotics 12".

The Spring School of the section of theoretical biology "Meaning and measurement of Biodiversity" took place at Roosta, Lääne county, September 28-30. This seminar was organized together with Institute of Ecology and Earth Sciences of University of Tartu and with Doctoral School of Earth Sciences and Ecology. During three days 16 scientific reports were presented.

In the section of botany three meetings were held:

1. February 6, presentation by Mare Leis "Where come the new moss species into the Estonian list from?";

2. October 10, presentation by Ülle Reier "Known and unknown Mongolia";

3. November 21, presentation by Bellis Kullmann "Species of fungus - what is it?" 
The next issue of internet journal "Friend of mosses, 15" was compiled (http://www.botany.ut.ee/bruoloogia/). Gathering of the friends of mosses took place at Äntu Landscape Reserve, Lääne-Viru county, June 2-3.

The observers network in the section of amateur meteorologists continued their work in 62 stations all over the Estonia. This data were analyzed and most important agrometeorological indexes were found out. Observation results of those 62 stations were used together with data of Estonian Meteorological and Hydrological Institute to draw up different meteorological maps (www. sordiaretus.ee).

Gathering of amateur meteorologists and thunder observers took place at Alatskivi, Tartu county, July 21. 6 reports were presented by scientists from University of Tartu, Estonian Meteorological and Hydrological Institute and Jõgeva Plant Breeding Institute.

Estonian Teriological Society organized the $19^{\text {th }}$ Autumn School "Mammalia" at Nigula Nature Reserve, Pärnu county, October 12-14. During those days 12 scientific reports were presented and two workshops took place.

The section of anthropology organized together with Institute of History of Tallinn University and with NGO Centre of Archaeology a $6{ }^{\text {th }}$ Science day dedicated to the $90^{\text {th }}$ anniversary of Karin Mark "Eating is necessary - the food nowadays and old-time”, March 29. Four scientific reports were presented during this seminar.

Conference commemorating the $113^{\text {th }}$ anniversary of Juhan Aul (18971994) was organized together with the Centre for Physical Anthropology of the University of Tartu. Five scientific reports were presented together with a new issue of the journal "Papers on Anthropology XXI".

Estonian Mycological Society organized two mushroom practice in Lääne county, May 5-7 and September 24-27. Meeting of Mycological society "Actiones" took place on December 8, where five scientific reports were presented.

Together with University of Tartu the next issue of Folia Cryptogamica Estonica was published (http://www.ut.ee/ial5/fce/index.html).

The section of forestry had four scientific seminars during 2012:

January 10 (together with the Department of forest management, University of Life Sciences), Allan Sims: "Managing data in ForMIS";

March 29, Kalev Jõgiste: "Nine months in America as scientist"; 
October 17, Allar Padar: "Potential amount of logging residues, buildup and consumption";

December 3 (together with Department of forest management, University of Life Sciences), Regino Kask: "The impact of growth condition to timber quality of Scotch pine (Pinus sylvestris L.)"

A monograph "Scotch pine in Estonia" (420 pp.) was compiled and edited by Malle Kurm.

The Society participated in fulfilling the projects funded by the Environmental Investment Centre, Tallinn Botanic Garden and the Environmental Board. ENS and The Estonian Environment Information Centre developed the Nature Observation Database (http://loodus.keskkonnainfo.ee/LVA/LVA.aspx).

In December 2012 there were 162554 printed items in ENS library. Within a year library acquired 84 new books and items of 226 periodicals. The publications were exchanged in the reporting year with 54 institutions and organisations from 18 countries.

\section{PUBLICATIONS}

1. Niklus M. (translation), Viikmaa M., Puura I., Tinn O. (eds.). 2012. Darwin, Charles. Liikide tekkimine loodusliku valiku teel ehk soodustatud rasside säilimine olelusvõitluses. Loodusteaduste klassikuid 2. Tartu. 548 pp.;

2. Laanisto L., Öpik M., Vanatoa A., Kull K. (eds.). 2012. Elurikkuse mõte ja mõõt. Schola Biotheoretica XXXVIII. Tartu. 159 pp.

3. Laumets L., Lang L., Truuver K., Nemliher R. (eds.). 2012. Katastroofid Maa ajaloos. Schola Geologica VIII. Tartu. $136 \mathrm{pp}$.

4. Folia Cryptogamica Estonica 49.98 pp. (with the University of Tartu; http://www.ut.ee/ial5/fce/index.html)

\section{INTERNET JOURNAL}

Ingerpuu N., Vellak K. (eds.) 2012. „Friend of mosses” 15.40 pp.

(http://www.botany.ut.ee/bruoloogia/Samblasober15.pdf)

\section{Address for correspondence:}

Tõnu Viik

Tartu Observatory

Tartumaa, 61602, Estonia

E-mail: viik@aai.ee 